\title{
Hormesis effects of phosphorus on the viability of Chlorella regularis cells under nitrogen limitation
}

\author{
Liang Fu', Qingcheng Li', Ge Yan', Dandan Zhou ${ }^{1 *}$ (1) and John C. Crittenden ${ }^{1,2}$
}

\begin{abstract}
Background: Phosphorus (P) is an essential element of microalgae, which is either required for anabolism or for energy metabolism. When employing a nitrogen limitation strategy to trigger microalgal intracellular lipid accumulation, P supplementation was always simultaneously applied to compensate for the accompanied growth inhibition.

Results: This study identified that $P$ exerts hormesis effects on microalgae. Slight excess of $P\left(\leq 45 \mathrm{mg} \mathrm{L}^{-1}\right)$ under nitrogen limitation condition stimulated the cell growth of Chlorella regularis and achieved a $10.2 \%$ biomass production increase. This also improved mitochondrial activity by $25.0 \%$ compared to control $\left(P=5.4 \mathrm{mg} \mathrm{L}^{-1}\right)$. The lipid productivity reached $354.38 \mathrm{mg}(L d)^{-1}$, which increased by $39.3 \%$ compared to control. Such an improvement was caused by the intracellularly stored polyphosphate energy pool. However, large excess of $\mathrm{P}\left(250 \mathrm{mg} \mathrm{L}^{-1}\right)$ inhibited the cell growth by $38.8 \%$ and mitochondrial activity decreased by $71.3 \%$. C. regularis cells showed obvious poisoning status, such as enlarged size, plasmolysis, deformation of cell walls, and disorganization of organelles. This is probably because the over-accumulated $\mathrm{P}$ protonated the amide- $\mathrm{N}$ and disrupted membrane permeability.
\end{abstract}

Conclusions: These results provide new insight into the roles of $\mathrm{P}$ in microalgae lipid production: $\mathrm{P}$ does not always play a positive role under nitrogen limitation conditions.

Keywords: Microalgae, Phosphorus, Hormesis, Nitrogen limitation, Toxic

\section{Background}

Microalgae are a promising feedstock for biodiesel [1,2]. In their studies on microalgae bioenergy technologies in the past 40 years, researchers have endeavored to explore strategies for enhancing biomass production and lipid accumulation [3, 4], which taken together, determines microalgal lipid production. Nitrogen limitation is the most popular approach to increase the microalgal lipid content, because it is able to up-regulate the key enzymes on the lipid biosynthesis pathways: malic enzymes become more activated for catalyzing pyruvate synthesis and NADPH (reduced nicotinamide adenine dinucleotide phosphate) formation and both acetyl-CoA and ATP

\footnotetext{
*Correspondence: zhoudandan415@163.com

${ }^{1}$ Engineering Lab for Water Pollution Control and Resources Recovery, School of Environment, Northeast Normal University, Changchun 130117, People's Republic of China

Full list of author information is available at the end of the article
}

(adenosine triphosphate)-citrate lyase are stimulated for catalyzing acetyl-CoA production $[5,6]$. The lipid content could be enhanced by $10-50 \%$ when nitrogen was limited $[4,7]$, and even up to two- to three-fold during nitrogen starvation $[8,9]$.

Even though nitrogen deprivation/limitation promoted intracellular lipid accumulation, it also decreased biomass production by as much as $80 \%$, and caused the failure of final lipid production improvement $[10,11]$. Nitrogen deprivation/limitation could weaken proteins synthesis, and thus induce the depletion of ADP (adenosine diphosphate) and NADP (nicotinamide adenine dinucleotide phosphate) and the dysfunction of cell synthesis $[12,13]$. Phosphorus (P) supplementation offered an effective strategy to resolve these problems and has thus been employed to enhance microalgae biomass production under nitrogen limitation $[14,15]$. Combining nitrogen limitation with $\mathrm{P}$ 
supplementation could contribute $10-100 \%$ increase on the microalgae biomass production, accompanied by $15-50 \%$ improvement of lipid accumulation, and finally achieved 50-160\% enhancement of lipid productivity $[4,15,16]$. In a P-repletion condition, $\mathrm{P}$ was stored as intracellular polyphosphate (poly-P) by microalgae both in autotrophic and heterotrophic growth [17, 18]. Poly-P, with phosphoanhydride bonds, was rich in energy (e.g., ATP), which could be utilized for biosynthesis when cells were nitrogen deprived [14]. In addition, poly-P can also be metabolized to form DNA (deoxyribonucleic acid), RNA (ribonucleic acid), or intermediate products in microalgae [5]. Thus, replete phosphorus has traditionally been suggested to benefit microalgae growth and lipid accumulation $[4,11]$.

Excess $\mathrm{P}$ is advantageous for microalgal lipid production; however, it also increases the cost of cultivation. Agricultural and industrial wastewater are promising P sources. Piggery wastewater, dairy wastewater, brewery wastewater, food processing wastewater, and rubber mill wastewater, are all rich in $\mathrm{P}$ [19-22]. The $\mathrm{P}$ concentrations in these industrial wastewaters range widely from 3 to $330 \mathrm{mg} \mathrm{L}^{-1}$. However, previous studies on $\mathrm{P}$ supplementation improved microalgal cultivation, which was limited by the slight excess of $\mathrm{P}$ $\left(\leq 45 \mathrm{mg} \mathrm{L}^{-1}\right)$. The question remains whether large excess of $\mathrm{P}$ can continuously increase the lipid production of microalgae. The answer may be negative. Whether an environmental agent is beneficial or toxic depends on its dosage, which is referred to as hormesis. Hormesis is a biphasic dose-response to an environmental agent, i.e., a low dose stimulation has a beneficial effect and a high dose has inhibitory or toxic effects [23]. Based on this, slight excess of $\mathrm{P}\left(\leq 45 \mathrm{mg} \mathrm{L}^{-1}\right)$ could stimulate cell growth [4]; however, the effects of large $P$ excess still remain unknown. The results of this study provide new insight for the application of microalgae in P-bearing wastewater treatment.

In this study, the roles of $\mathrm{P}$ on Chlorella regularis (C. regularis, model strain) were investigated in a wide concentration range $\left(5.4-250 \mathrm{mg}-\mathrm{P} \mathrm{L}^{-1}\right)$ under nitrogen limiting conditions. The effects of $\mathrm{P}$ concentration on cell growth (which were determined via cell density changes and substrates consumption), and intracellular lipid accumulation (which was related to the intracellular contents) were studied. In addition, mitochondrial activity assay, ultrastructure morphology of cells, intracellular-P storage forms, and chemical bond analyses were conducted, to identify the potential mechanism underlying $\mathrm{P}$ toxicity. Interestingly, hormesis effects of $\mathrm{P}$ on microalgae cells were confirmed, which specified the toxic of high $\mathrm{P}$ concentration on microalgae for the first time.

\section{Methods}

\section{Microalgae strain, cultivation, and protocols}

As a typical microalga, C. regularis var. minima (FACHB729) was used in this study, which was purchased from the Freshwater Algae Culture Collection of the Institute of Hydrobiology in Wuhan, China. Prior to the experiments, $C$. regularis was purified via the streaking plating method and preserved on agar jelly at $4{ }^{\circ} \mathrm{C}$. Before the experiment, C. regularis was activated using classic BG11 medium under photoautotrophic condition [24]. As an inoculum of the experiment, the activated $C$. regularis cells were collected at the logarithmic phase (20 days of phototrophic cultivation) via centrifuging $(6000 \times g$ for $5 \mathrm{~min}$ at $4{ }^{\circ} \mathrm{C}$ ), and then washed and re-suspended three times with $0.9 \%$ sterile physiological saline. After the above procedures, $C$. regularis was inoculated into the modified BG11 media, which resulted in an initial cell density of $1.5 \times 10^{7}$ cell $\mathrm{mL}^{-1}$ for further heterotrophic at $28^{\circ} \mathrm{C}, 160 \mathrm{rpm}$, in the dark (ZWY-240, Zhicheng Shanghai, China). During the experiments, all sampling operations were accomplished in a clean bench (SW-CJ-1FD, Airtech, Suzhou, China).

Real wastewater with high $\mathrm{P}$ concentration also has high levels of organics [21, 25]. Accordingly, glucose was selected to simulate organic carbon for microalgae heterotrophic cultivation $[11,26]$. In this study, $10 \mathrm{~g} \mathrm{~L}^{-1}$ glucose (sterilized using sterile $0.22 \mathrm{~mm}$ filter) was mixed to the BG11 mediums to create heterotrophic cultivation. Nitrogen limitation was controlled by adding $300 \mathrm{mg} \mathrm{L}^{-1} \mathrm{NaNO}_{3}$. The form of nitrogen was identical to the BG11 medium; however, its content was only $20 \%$ of the classic BG11 [4]; therefore, this condition was named nitrogen limitation $\left(\mathrm{N}_{\text {lim }}\right)$. Furthermore, a series of phosphorus $\left(\mathrm{PO}_{4}{ }^{3-}-\mathrm{P}\right)$ levels were proposed to elaborate the effects of $\mathrm{P}$ concentration $\left(\mathrm{mg} \mathrm{L}^{-1}\right), 5.4,25,45$, 150 , and $250 \mathrm{mg} \mathrm{L}^{-1}$. The $5.4 \mathrm{mg}-\mathrm{P} \mathrm{L}^{-1}$ was equal to the $\mathrm{P}$ concentration of the classic BG11 medium; therefore, it was used as control protocol $\left(\mathrm{N}_{\lim } \mathrm{P} 5.4\right)$. The others were called $\mathrm{N}_{\text {lim }}$ P25, $\mathrm{N}_{\text {lim }}$ P45, $\mathrm{N}_{\text {lim }}$ P150, and $\mathrm{N}_{\text {lim }}$ P250 in the following. Additionally, $\mathrm{MgSO}_{4}, \mathrm{NaCO}_{3}, \mathrm{CaCl}_{2}$, citric acid, ammonium ferric citrate, $\mathrm{Na}_{2} \mathrm{EDTA}, \mathrm{H}_{3} \mathrm{BO}_{3}$, $\mathrm{MnCl}_{2}, \mathrm{ZnSO}_{4}, \mathrm{CuSO}_{4}, \mathrm{CoCl}_{2}$, and $\mathrm{NaMoO}_{4}$ were also supplemented as nutrients and trace elements according to a previous study [11]. The medium was autoclaved at $121{ }^{\circ} \mathrm{C}$ for $30 \mathrm{~min}$, and the final $\mathrm{pH}$ was about 7.1 adjusted with sterile $\mathrm{HCl}$ and $\mathrm{NaOH}$ solution and no precipitation appeared in the medium.

\section{Growth profiles and nutrient consumptions}

Microalgal growth was evaluated via cell density [10], obtained with an optical microscope (BX53, Olympus, Japan) coupled with a hemocytometer. The results were determined based on the averages of at least three 
repetitions. The cell growth rate was calculated according to Eq. (1):

$$
\text { Cell growth rate }\left(\text { cell }(\mathrm{mL} \mathrm{d})^{-1}\right)=\left(X_{2}-X_{1}\right) /\left(t_{2}-t_{1}\right)
$$

where $X_{1}$ and $X_{2}$ (cell $\mathrm{mL}^{-1}$ ) represent the cell density at times $t_{1}$ and $t_{2}$, respectively; $t_{1}$ and $t_{2}$ represent the initial and final point within the linear portion of Fig. 1a.

Organics, phosphorus, and nitrogen consumptions were of particular concern, which were represented by the changing of chemical oxygen demand (COD), dissolved inorganic nitrogen (DIN), and dissolved inorganic phosphorus (DIP) in this work. These were determined via spectrophotometry using a water quality analyzer and the provided reagent kits (5B-3C V8, Lian Hua Technology, China) according to the manufacturer's instructions. Prior to measurements, the samples were filtered with $0.45 \mu \mathrm{m}$ cellulose acetate membranes to remove any suspended residues and biomass.

\section{Intracellular storage products: lipid, protein, and starch}

The cells were collected on day 4 via centrifugation at $10,610 \times g$ for $10 \mathrm{~min}$ at $4{ }^{\circ} \mathrm{C}$ (TGL-16M, Cence, China), and were then freeze-dried (Pilot1-2LD, Boyikang, China) at $-80{ }^{\circ} \mathrm{C}$. The achieved lyophilized powder was used for lipid extraction using the chloroform-methanol $(2: 1 \mathrm{v} / \mathrm{v})$ reagent method [27]. Therefore, the lipid content could be calculated based on the gravimetric ratio of the extract and the powder and the lipid productivity was determined based on the following equation [28]:

$$
\begin{aligned}
& \text { Lipid productivity }\left(\mathrm{mg}(\mathrm{L} \mathrm{d})^{-1}\right) \\
& \quad=\left(B_{2} \times C_{2}-B_{1} \times C_{1}\right) /\left(T_{2}-T_{1}\right)
\end{aligned}
$$

where $B_{1}$ and $B_{2}$ represent the biomass $\left(\mathrm{mg} \mathrm{L}^{-1}\right)$ at the times $T_{1}$ and $T_{2}$, respectively; $C_{1}$ and $C_{2}$ represent the lipid content (\%) at times $T_{1}$ and $T_{2}$, respectively. $T_{1}$ and $T_{2}$ represent the sampling time at initial and day 4 .

To measure protein and starch, the cells were pretreated via ultrasound at $1500 \mathrm{~W},-4{ }^{\circ} \mathrm{C}$ for $30 \mathrm{~min}$ to break the cell-walls. Then, the solution was filtered with a $0.45 \mu \mathrm{m}$ cellulose acetate membrane to remove fragments. The filtrate was ready for intracellular protein and starch evaluation. A folin-phenol assay kit (Dingguo Changsheng Biotechnology, Beijing, China) was employed for protein analysis [29]. For the hydrolysis of starch, 30\% perchloric acid was added to the filtrate and stirred at $25{ }^{\circ} \mathrm{C}$ for $15 \mathrm{~min}$, the extracts were analyzed with the anthrone method [30].

\section{Mitochondrial activity assay}

The mitochondrial activity was determined with the 3-(4,5-dimethyl-2-thiazolyl)-2,5-diphenyl-2H-tetrazo-


Fig. 1 C. regularis growth profiles (a), the cell growth rate $(\mathbf{b})$, and DIP consumptions (c) when P concentrations were $5.4 \mathrm{mg} \mathrm{L}^{-1}\left(\mathrm{~N}_{\text {lim }} \mathrm{P} 5.4\right)$, $25 \mathrm{mg} \mathrm{L}^{-1}\left(\mathrm{~N}_{\text {lim }} \mathrm{P} 25\right), 45 \mathrm{mg} \mathrm{L}^{-1}\left(\mathrm{~N}_{\text {lim }} \mathrm{P} 45\right), 150 \mathrm{mg} \mathrm{L}^{-1}\left(\mathrm{~N}_{\text {lim }} \mathrm{P} 150\right)$, and $250 \mathrm{mg} \mathrm{L}^{-1}\left(\mathrm{~N}_{\text {lim }} \mathrm{P} 250\right)$. Error bars represent standard deviations, which were obtained based on triplicate measurements

lium bromide (MTT) assay kit (Beyotime, Beijing, China) according to a previous publication [31]. Briefly, the cells were seeded to a 96 -well plate $\left(5 \times 10^{5}\right.$ cells $\left.\mathrm{mL}^{-1}\right)$ and were incubated with fresh air ventilated $\left(5 \% \mathrm{CO}_{2}\right)$, at 
$37{ }^{\circ} \mathrm{C}$. After $48 \mathrm{~h}, 10 \mu \mathrm{L}$ MTT $\left(5 \mathrm{mg} \mathrm{mL}^{-1}\right)$ was added to the wells for another $4 \mathrm{~h}$ of incubation. The absorbance of the culture was measured at $570 \mathrm{~nm}$ using a microplate reader (RT-6000, Rayto, China).

\section{Morphology and ultrastructure of cells}

Microalgal cell morphology was observed via optical microscopy (BX53, Olympus, Japan) and scanning electron microscopes (SEM) (XL-30 FE-SEM, FEI Co., USA). The ultrastructure of the cell was observed with a transmission electron microscope (TEM) equipped with an energy dispersive X-ray spectrometer (EDX) (JEM 1200EX, JEOL, Japan). Prior to SEM and TEM observation, the cells were pretreated by a series of multiple fixative and dehydrated procedures [32, 33]. Before TEM-EDX analysis, the dehydrated cells should be embedded in epoxy resin (Epon812, Shell Chemical, USA) for cutting (Microtome, Leica UCT, Germany) and ultrathin sections were further stained with uranyl acetate [34].

\section{${ }^{31} \mathrm{P}$ nuclear magnetic resonance spectroscopy (NMR)}

The P-storage compounds in microalgal cells were extracted via the ice-cold $\mathrm{HClO}_{4}$ method $[14,35]$, and then $10 \% \mathrm{D}_{2} \mathrm{O}$ was added to provide a field-frequency lock. The ${ }^{31} \mathrm{P}$ NMR spectra were acquired at $400 \mathrm{MHz}$ with a $5 \mathrm{~mm}$ probe using an NMR spectrometer (Vnmrs300, Varian Co., USA). The acquisition time was $16 \mathrm{~h}$ at room temperature. MestReNova software 11 was used to analyze the peaks in the spectra, and the P compounds were identified by their chemical shifts based on the previously published spectra [35-37].

\section{X-ray photoelectron spectroscopy (XPS)}

The binding energies of N1s and P2p were analyzed to investigate the character of the intracellular compounds via XPS (ESCALAB 250, Thermo, USA). The sample was the lyophilized powder of microalgal cells, which was obtained via the above-mentioned freeze-drying method. The beam source type was $\mathrm{Al} \mathrm{K} \mathrm{Alpha,} \mathrm{and} \mathrm{it} \mathrm{was} \mathrm{operat-}$ ing at $250 \mathrm{~W}$, a voltage of $15 \mathrm{kV}$, a current of $15 \mathrm{~mA}$, an energy of $1486.71 \mathrm{eV}$; the sampling spot size was $500 \mu \mathrm{m}$ in diameter and an electron takeoff angle of $50^{\circ}$ was used. The binding energy was calibrated with reference to $\mathrm{C} 1 \mathrm{~s}$ at $284.8 \mathrm{eV}$ in the spectra analysis with XPS Peak 4.1 software [38].

\section{Statistical analysis}

$\mathrm{P}$ concentration effects were investigated based on triplicate cultivations, and then the statistically significances were analyzed using one-way ANOVA method. The mean values were compared using a least significant difference (LSD) test. Differences were significant when
$P<0.05$. All statistical analyses were performed using the SPSS software package (IBM SPSS statistic 20.0).

\section{Results and discussion}

Effect of $\mathrm{P}$ concentrations on $\mathrm{C}$. regularis growth

The cell density of C. regularis was $\sim 4.70 \times 10^{7}$ cell $\mathrm{mL}^{-1}$ at the stationary stage when $\mathrm{P}$ supply was regular, $\mathrm{N}_{\lim }$ P5.4 (refers to the classic BG11), see Fig. 1a. The cell density was about $76 \%$ of that in NP5.4 [18], indicating that nitrogen limitation inhibited cell growth. Microalgal growth was stimulated when $\mathrm{P}$ was slightly excessive, i.e., the cell density increased by $10.2 \%$ for $\mathrm{N}_{\lim } \mathrm{P} 45(P<0.05)$. A considerable number of previous studies reported that such a stimulation was caused by storage of excess P, under either autotrophic or heterotrophic cultivations [4, 14, 39, 40], where nitrogen was either limited or unlimited [41]. Excessive P induced improvements on supplying phospholipid, genetic materials, and energy for cell division $[42,43]$. However, further increasing of the P supply could result in microalgal growth inhibition. The cell density decreased for $\mathrm{N}_{\text {lim }} \mathrm{P} 150$ and decreased as much as $38.8 \%$ for $\mathrm{N}_{\text {lim }} \mathrm{P} 250$, compared to the control $\left(\mathrm{N}_{\mathrm{lim}} \mathrm{P} 5.4\right)$ $(P<0.05)$. In addition, the growth rate in Fig. 1b intuitively shows that the effects of $P$ depended on its concentration $(P<0.05)$. These results indicate that $C$. regularis growth was promoted when $\mathrm{P}$ was at an appropriate level; however, a large excess of $P$ had a negative impact on the cells. This is a typical manifestation of hormesis [44, 45].

Glucose, nitrogen, and phosphorus uptake profiles were represented by COD, DIN, and DIP changing versus time, respectively, see Additional file 1: Fig. S1 and Fig. 1c. The organic and nutrient consumptions were consistent with the growth profiles: stimulated by low $\mathrm{P}$ concentrations $\left(\mathrm{P} \leq 4.49 \times 10^{-7} \mathrm{mg}\right.$ cell $\left.\mathrm{mL}^{-1}\right)$ and slowing down at high $\mathrm{P}$ levels $\left(\mathrm{P} \geq 14.97 \times 10^{-7} \mathrm{mg}\right.$ cell $\left.\mathrm{mL}^{-1}\right)$. It is worth mentioning that $\mathrm{P}\left(\mathrm{PO}_{4}{ }^{3-}-\mathrm{P}\right)$ was completely consumed within 4 days when $\mathrm{P}$ was in slight excess (less than $45 \mathrm{mg} \mathrm{L}^{-1}$ ); in contrast, a large amount of $\mathrm{P}$ $\left(\mathrm{PO}_{4}{ }^{3-}-\mathrm{P}\right)$ remained for both $\mathrm{N}_{\text {lim }} \mathrm{P} 150$ and $\mathrm{N}_{\text {lim }} \mathrm{P} 250$ (Fig. 1c). These results implied that the capability of $P$ storage reached a threshold, above which, $\mathrm{P}$ may cause microalgal cell damage.

\section{Effects of $\mathrm{P}$ concentration on lipid productivity}

It seemed that $\mathrm{P}$ supply affected the carbon flow of the microalgal glucose metabolism. The lipid content enhanced by $22.9 \%$ for slightly excessive $\mathrm{P}\left(\mathrm{N}_{\text {lim }} \mathrm{P} 45\right)$ $(P<0.05)$. However, lipid synthesis was significantly suppressed when $C$. regularis cells were inhibited by a large excess of $\mathrm{P}\left(\mathrm{N}_{\lim } \mathrm{P} 250\right)$, whereas the lipid content decreased by $15.9 \%$ in comparison to the control $\left(\mathrm{N}_{\mathrm{lim}} \mathrm{P} 5.4\right)(P<0.05)$. For the cell density (Fig. 1a), 
the highest lipid productivity of $354.38 \mathrm{mg}(\mathrm{L} \mathrm{d})^{-1}$ was achieved for $\mathrm{N}_{\text {lim }} \mathrm{P} 45$, which increased by $39.3 \%$ in comparison to the control $(P<0.05)$. However, the lipid productivity of $C$. regularis for $\mathrm{N}_{\text {lim }} \mathrm{P} 250$ was only $47.3 \%$ of $\mathrm{N}_{\text {lim }} \mathrm{P} 45$ and decreased by $34.2 \%$ in comparison to control $(P<0.05)$. Accordingly, the intracellular protein and starch contents both positively correlated with P supply, as shown in Fig. 2a.

It has previously been reported that $\mathrm{P}$ enhances both microalgal lipid synthesis and production. P-replete favored the enzymes of the up-regulation of the lipid synthesis pathway [40] and could enhance the biomass production by activating phosphofructokinase and pyruvate kinase related glycolysis [46]. Here, for the first time, the toxicity of a large excess of $\mathrm{P}$ was addressed in microalgae. Excessive P dosage does not always increase the lipid production of microalgae under nitrogen limitation.

\section{Hormesis mechanism}

\section{Effect of $P$ concentration on cell viability}

Mitochondrial activity was used to study the microbial viability [31, 47], since more than $95 \%$ energy is generated in mitochondria, which are the "powerhouses" of the cell [48]. In this work, the trend of mitochondrial activity again supported $\mathrm{P}$ hormesis deduction, as shown in Fig. 3. Mitochondrial activity was stimulated and consequently increased by $25.0 \%(P<0.05)$, when $P$ was only slightly excessive $\left(\mathrm{N}_{\text {lim }} \mathrm{P} 45\right)$. However, it decreased as much as $71.3 \%$ for $\mathrm{N}_{\lim } \mathrm{P} 250(P<0.05)$, indicating dysfunction of mitochondria due to the toxicity of the large excess of $\mathrm{P}$.

\section{Cell morphology and ultrastructure}

Cell morphology and ultrastructure further corroborated the hormesis mechanism of P. C. regularis cells of

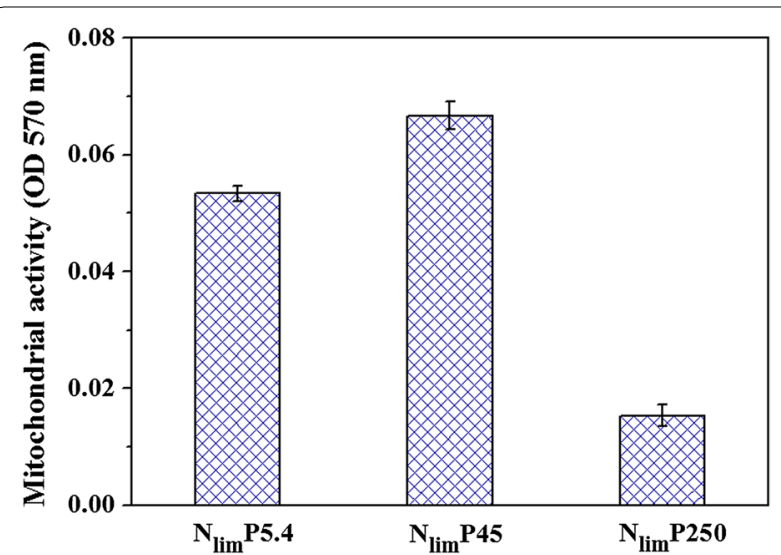

Fig. 3 Effect of $\mathrm{P}$ concentrations on mitochondrial activity of $C$. regularis under nitrogen limitation, with $P 5.4$, 45, and $250 \mathrm{mg} \mathrm{L}^{-1}$ $\left(\mathrm{N}_{\lim } \mathrm{P} 5.4, \mathrm{~N}_{\lim } \mathrm{P} 45\right.$, and $\mathrm{N}_{\lim } \mathrm{P} 250$, respectively). Error bars were obtained based on triplicate measurements

$\mathrm{N}_{\text {lim }} \mathrm{P} 45$ had a round shape, integrated structure, and intact organelles (Fig. 4a-c). All of these characteristics were identical to control cells. In contrast, the cells became folded for $\mathrm{N}_{\text {lim }} \mathrm{P} 250$, and several cells enlarged, reaching up to two- to three-fold of the size of the control (Fig. 4d, e). TEM images further showed that the cell walls thinned and even detached. Such damage of the plasma membrane and the following plasmolysis caused the described cell surface folding [49]. In addition, several organelles, such as mitochondria, were disordered when P was in large excess (Fig. 4f). These signs indicate targeted $\mathrm{P}$ poisoning of microalgal cells.

\section{Intracellular P distribution and the role of polyphosphates}

$\mathrm{P}$ distributions in $C$. regularis cells were different between stimulated $\left(\mathrm{N}_{\lim } \mathrm{P} 45\right)$ and inhibited $\left(\mathrm{N}_{\lim } \mathrm{P} 250\right)$ cell growth. P was mainly found in the intracellular








Fig. 4 Morphology of surface and inner C. regularis cells cultivated under two conditions (nitrogen limitation and P $45 \mathrm{mg} \mathrm{L}^{-1}, \mathrm{~N}_{\text {lim }} \mathrm{P} 45$, a-c; nitrogen limitation and P $250 \mathrm{mg} \mathrm{L}^{-1}, \mathrm{~N}_{\lim } \mathrm{P} 250, \mathbf{d}-\mathbf{f}$ ) with beneficial and inhibition effects for growth. The subfigures in $\mathbf{b}$ and $\mathbf{e}$ show representative enlarged views of cells. The red, blue, orange, and green arrows indicate light colored cells, large sized cells, fold structure, and lysed cells devoid of recognizable contents, respectively. cw cell wall, $p m$ plasma membrane, $m$ mitochondria

region for $\mathrm{N}_{\text {lim }} \mathrm{P} 45$ (4.13\% in weight), while it was located at the cell periphery for $\mathrm{N}_{\text {lim }} \mathrm{P} 250$ (5.4\% in weight), see Fig. 5. P in C. regularis formed poly-Ps (small black spots in TEM) in the cells for $\mathrm{N}_{\lim } \mathrm{P} 45$, which were at the resonances in -5 to -7 and -17 to $-22 \mathrm{ppm}[35,36]$ in the ${ }^{31} \mathrm{P}$ NMR spectra (Fig. 5). The poly-Ps also convinced by the peaks at $129.4 \mathrm{eV}$ and $137.1 \mathrm{eV}$ [50] in P 2p XPS spectra (Fig. 5). Poly-P served as an energy pool to stimulate cell division and metabolism [37].

However, the forms of poly-P became different when the excess poly-P was stored for C. regularis $\left(\mathrm{N}_{\text {lim }} \mathrm{P} 250\right)$. The poly-Ps located near the cell periphery, which likely damaged both plasma membrane and cell wall (Fig. 5). In addition, mitochondria were disordered, as the peaks ( $-11.5 \mathrm{ppm})$ of ATP and NADH [35] almost disappeared in ${ }^{31} \mathrm{P}$ NMR spectra for $\mathrm{N}_{\text {lim }} \mathrm{P} 250$ (Fig. 5). This indicated that excess poly-Ps damaged the energy production process, which was consistent with the results on growth inhibition and mitochondrial activity decrement. Consequently, the excess poly-P accumulation disintegrated the thylakoid membranes and resulted the cell lysis and cell death at the end [51]. Moreover, excess poly-P was able to form dinucleoside polyphosphates with similar structure to ATP and other essential mononucleotides; therefore, it was also toxic for cells and caused DNA damage in the intra-S phase [52].

Excess poly-P could bind to intracellular components and inhibit cell viability [18]. There were several new peaks at $-7.7 \mathrm{ppm}$ and $-19.8 \mathrm{ppm}$ in the ${ }^{31} \mathrm{P}$ NMR spectra, which indicated that the new form of $\mathrm{P}$ appeared for $\mathrm{N}_{\text {lim }}$ P250 (Fig. 5). This was also confirmed by the peak at higher binding energy of $139.8 \mathrm{eV}$ in the P 2p XPS spectra (Fig. 5), which represented the binding compounds of poly-P to intracellular components [18]. Furthermore, a new peak of protonated amide- $\mathrm{N}$ in protein at $402.3 \mathrm{eV}$ [53, 54] appeared for $\mathrm{N}_{\text {lim }}$ P250 (Fig. 6). It seems that the excess poly-P bonded to the proteins and resulted protonated amide- $\mathrm{N}$, which affected the binding of the protein-ligand [55]. Thus, a major constraint in protein breakage and large cytoplasmic crevices appeared, followed by interfered interactions of protein subunits [55]. The changes on channel and transporter proteins 


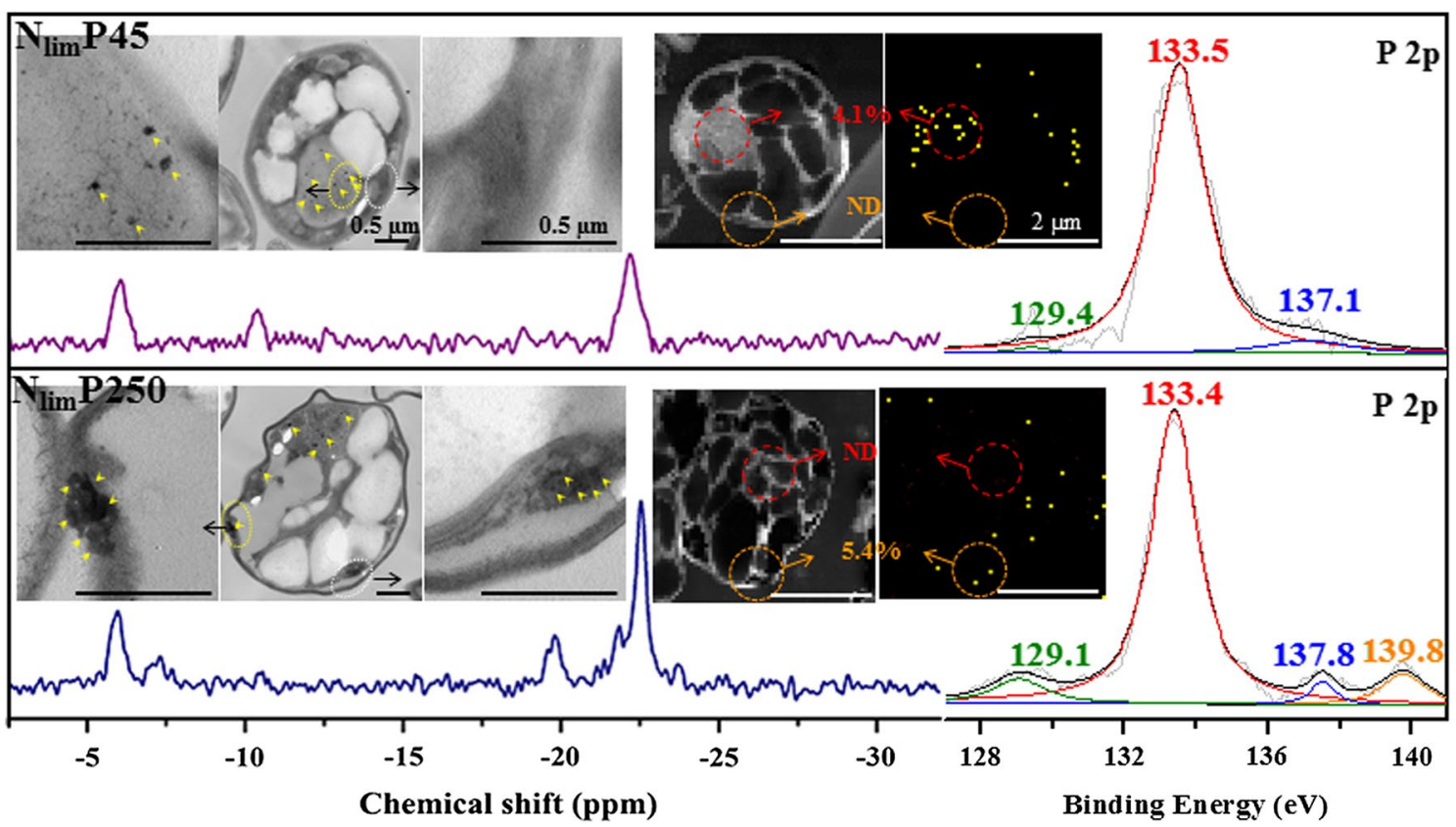

Fig. $5{ }^{31}$ P NMR spectra and P 2p XPS spectra in C. regularis cells, with magnified TEM and P elemental mapping images inserted. The yellow arrows indicate poly-P granules. The red circle shows the inner cell area, the orange circle shows the cell wall area. The data from the red and orange circles indicates the weight percentage of $\mathrm{P}$ in the circle area, ND means not detected

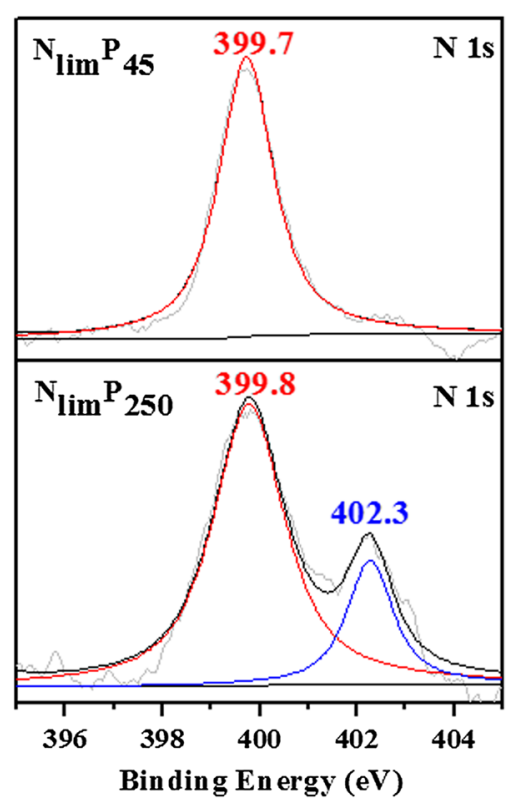

Fig. 6 N 1s XPS spectra of C. regularis cells. The microalgal cells were freeze-dried to obtain lyophilized powder for XPS analysis

induced the across membrane process of ions and disordered small molecules [56]. In this way, membrane permeability was damaged and membrane proteins were disrupted [57].

\section{Conclusions}

$P$ presented a hormesis effects for microalgal cultivation. Slightly excessive P levels $\left(\leq 45 \mathrm{mg} \mathrm{L}^{-1}\right)$ stimulated C. regularis enhancement of growth (10.2\%), lipid accumulation (22.9\%), and mitochondrial activity (25.0\%) via poly-P storage energy. The total lipid productivity increased by $39.3 \%$. In contrast, large excess of $P$ $(\mathrm{P} \geq 150 \mathrm{mg} / \mathrm{L})$ poisoned C. regularis cells, which showed enlarged size, plasmolysis, deformation of cell walls, and disorganization of organelles. Both cell density and mitochondrial activity decreased by $38.8 \%$ and $71.3 \%$, respectively, followed by a decrease of the final lipid productivity of $34.2 \%$. The poisoning mechanisms are related to intracellular amide- $\mathrm{N}$ in protein protonation and the damage of the plasma membrane.

\section{Additional file}

Additional file 1: Fig. S1. The COD and DIN consumptions during C. regularis growth with different $\mathrm{P}$ concentrations. Error bars represent standard deviation values, which were obtained based on triplicate measurements.

\section{Abbreviations}

P: phosphorus; NADPH: reduced nicotinamide adenine dinucleotide phosphate; NADP: nicotinamide adenine dinucleotide phosphate; ATP: adenosine triphosphate; ADP: adenosine diphosphate; poly-P: polyphosphate; DNA: 
deoxyribonucleic acid; RNA: ribonucleic acid; C. regularis: Chlorella regularis; $\mathrm{N}_{\text {lim: }}$ : nitrogen limitation; COD: chemical oxygen demand; DIN: dissolved inorganic nitrogen; DIP: dissolved inorganic phosphorus; MTT: 3-(4,5-dimethyl2-thiazolyl)-2,5-diphenyl-2H-tetrazolium bromide; SEM: scanning electron microscopes; TEM: transmission electron microscope; EDX: energy dispersive $X$-ray spectrometer; NMR: nuclear magnetic resonance; XPS: X-ray photoelectron spectroscopy.

\section{Authors' contributions}

DZ conceived of this study, LF analyzed the experiment data and drafted the manuscript, LF and DZ revised the manuscript, QL and GY carried out microalgal cultivation and collected the experiment data, QL performed statistical analysis, JCC provided useful suggestions for this study and manuscript. All authors read and approved the final manuscript.

\section{Funding}

This research was supported by the National Natural Science Foundation of China (51708095, 51578117, 51722803), Fundamental Research Funds for the Central Universities (2412017QD027, 2412018ZD013, 2412018ZD042), the Science and Technology Project of Jilin Province (20180520168JH), China Postdoctoral Science Foundation (2017M611302, 2018T110241) for their financial support. We also thank Dr. Yanhong Xiao and Dr. Nan Lu, Experiment Center of School of Environment, Northeast Normal University for assistance with our experimental data acquisition.

\section{Availability of data and materials}

$$
\text { Not applicable. }
$$

\section{Ethics approval and consent to participate}

Not applicable.

\section{Consent for publication}

All the authors consent to publication.

\section{Competing interests}

The authors declare that they have no competing interests.

\section{Author details}

${ }^{1}$ Engineering Lab for Water Pollution Control and Resources Recovery, School of Environment, Northeast Normal University, Changchun 130117, People's Republic of China. ${ }^{2}$ Brook Byers Institute for Sustainable Systems, and School of Civil \& Environmental Engineering, Georgia Institute of Technology, Atlanta, GA 30332, USA.

Received: 8 January 2019 Accepted: 2 May 2019

Published online: 13 May 2019

\section{References}

1. Mata TM, Martins AA, Caetano NS. Microalgae for biodiesel production and other applications: a review. Renew Sustain Energy Rev. 2010;14:217-32.

2. Enamala MK, Enamala S, Chavali M, Donepudi J, Yadavalli R, Kolapalli B, Aradhyula TV, Velpuri J, Kuppam C. Production of biofuels from microalgae-a review on cultivation, harvesting, lipid extraction, and numerous applications of microalgae. Renew Sustain Energy Rev. 2018;94:49-68.

3. Brown N, Shilton A. Luxury uptake of phosphorus by microalgae in waste stabilisation ponds: current understanding and future direction. Rev Environ Sci Biotechnol. 2014;13:321-8.

4. Fu L, Cui X, Li Y, Xu L, Zhang C, Xiong R, Zhou D, Crittenden JC. Excessive phosphorus enhances Chlorella regularis lipid production under nitrogen starvation stress during glucose heterotrophic cultivation. Chem Eng J. 2017;330:566-72

5. Li Y, Han F, Xu H, Mu J, Chen D, Feng B, Zeng H. Potential lipid accumulation and growth characteristic of the green alga Chlorella with combination cultivation mode of nitrogen $(\mathrm{N})$ and phosphorus $(\mathrm{P})$. Bioresour Technol. 2014;174:24-32.

6. Liang MH, Qv XY, Chen H, Wang Q, Jiang JG. Effects of salt concentrations and nitrogen and phosphorus starvations on neutral lipid contents in the green microalga Dunaliella tertiolecta. J Agric Food Chem. 2017;65:3190-7.

7. Griffiths MJ, van Hille RP, Harrison STL. The effect of nitrogen limitation on lipid productivity and cell composition in Chlorella vulgaris. Appl Microbiol Biotechnol. 2014;98:2345-56.

8. Li Y, Horsman M, Wang B, Wu N, Lan CQ. Effects of nitrogen sources on cell growth and lipid accumulation of green alga Neochloris oleoabundans. Appl Microbiol Biotechnol. 2008;81:629-36.

9. Kamalanathan M, Pierangelini M, Shearman LA, Gleadow R, Beardall J. Impacts of nitrogen and phosphorus starvation on the physiology of Chlamydomonas reinhardtii. J Appl Phycol. 2016;28:1509-20.

10. Zhu S, Huang W, Xu J, Wang Z, Xu J, Yuan Z. Metabolic changes of starch and lipid triggered by nitrogen starvation in the microalga Chlorella zofingiensis. Bioresour Technol. 2014;152:292-8.

11. Shen XF, Chu FF, Lam PKS, Zeng RJ. Biosynthesis of high yield fatty acids from Chlorella vulgaris NIES-227 under nitrogen starvation stress during heterotrophic cultivation. Water Res. 2015;81:294-300.

12. Hu Q, Sommerfeld M, Jarvis E, Ghirardi M, Posewitz M, Seibert M, Darzins A. Microalgal triacylglycerols as feedstocks for biofuel production: perspectives and advances. Plant J. 2008:54:621-39.

13. Fields MW, Hise A, Lohman EJ, Bell T, Gardner RD, Corredor L, Moll K, Peyton BM, Characklis GW, Gerlach R. Sources and resources: importance of nutrients, resource allocation, and ecology in microalgal cultivation for lipid accumulation. Appl Microbiol Biotechnol. 2014;98:4805-16.

14. Chu FF, Chu PN, Cai PJ, Li WW, Lam PKS, Zeng RJ. Phosphorus plays an important role in enhancing biodiesel productivity of Chlorella vulgaris under nitrogen deficiency. Bioresour Technol. 2013;134:341-6.

15. Shen XF, Liu JJ, Chu FF, Lam PKS, Zeng RJ. Enhancement of FAME productivity of Scenedesmus obliquus by combining nitrogen deficiency with sufficient phosphorus supply in heterotrophic cultivation. Appl Energy. 2015;158:348-54

16. Chu FF, Chu PN, Shen XF, Lam PKS, Zeng RJ. Effect of phosphorus on biodiesel production from Scenedesmus obliquus under nitrogen-deficiency stress. Bioresour Technol. 2014;152:241-6.

17. Eixler S, Karsten U, Selig U. Phosphorus storage in Chlorella vulgaris (Trebouxiophyceae, Chlorophyta) cells and its dependence on phosphate supply. Phycologia. 2006;45:53-60.

18. Li Q, Fu L, Wang Y, Zhou D, Rittmann BE. Excessive phosphorus caused inhibition and cell damage during heterotrophic growth of Chlorella regularis. Bioresour Technol. 2018;268:266-70.

19. Chiu SY, Kao CY, Chen TY, Chang YB, Kuo CM, Lin CS. Cultivation of microalgal Chlorella for biomass and lipid production using wastewater as nutrient resource. Bioresour Technol. 2015;184:179-89.

20. Wang Y, Ho SH, Cheng CL, Guo WQ, Nagarajan D, Ren NQ, Lee DJ, Chang JS. Perspectives on the feasibility of using microalgae for industrial wastewater treatment. Bioresour Technol. 2016;222:485-97.

21. Jayakumar S, Yusoff MM, Ab Rahim MH, Maniam GP, Govindan N. The prospect of microalgal biodiesel using agro-industrial and industrial wastes in Malaysia. Renew Sustain Energy Rev. 2017;72:33-47.

22. Suzuki K, Waki M, Yasuda T, Fukumoto Y, Kuroda K, Sakai T, Suzuki N, Suzuki R, Matsuba K. Distribution of phosphorus, copper and zinc in activated sludge treatment process of swine wastewater. Bioresour Technol. 2010;101:9399-404.

23. Mattson MP. Hormesis defined. Ageing Res Rev. 2008;7:1-7.

24. Zhou D, Zhang C, Liang F, Liang X, Cui X, Li Q, Crittenden JC. Responses of the microalga Chlorophyta sp. to bacterial quorum sensing molecules ( $n$-acylhomoserine lactones): aromatic protein induced self-aggregation. Environ Sci Technol. 2017;51:3490-8.

25. Kamyab H, Din MFM, Keyvanfar A, Majid MZA, Talaiekhozani A, Shafaghat A, Lee CT, Shiun $L$, Ismail HH. Efficiency of microalgae chlamydomonas on the removal of pollutants from palm oil mill effluent (POME). Energy Procedia. 2015;75:2400-8.

26. Perez-Garcia O, Escalante FME, de-Bashan LE, Bashan Y. Heterotrophic cultures of microalgae: metabolism and potential products. Water Res. 2011;45:11-36

27. Bligh EG, Dyer WJ. A rapid method of total lipid extraction and purification. Can J Biochem Phys. 1959;37:911-7.

28. Zhang C, Li Q, Fu L, Zhou D, Crittenden JC. Quorum sensing molecules in activated sludge could trigger microalgae lipid synthesis. Bioresour Technol. 2018;263:576-82. 
29. Frolund B, Palmgren R, Keiding K, Nielsen PH. Extraction of extracellular polymers from activated sludge using a cation exchange resin. Water Res. 1996;30:1749-58.

30. Branyikova I, Marsalkova B, Doucha J, Branyik T, Bisova K, Zachleder V, Vitova M. Microalgae-novel highly efficient starch producers. Biotechnol Bioeng. 2011;108:766-76.

31. Li J, Song L. Applicability of the MTT assay for measuring viability of cyanobacteria and algae, specifically for Microcystis aeruginosa (Chroococcales, (yanobacteria). Phycologia. 2007:46:593-9.

32. Chen X, Zhang C, Tan L, Wang J. Toxicity of Co nanoparticles on three species of marine microalgae. Environ Pollut. 2018;236:454-61.

33. Gaertner G, Uzunov B, Ingolic E, Kofler W, Gacheva G, Pilarski P, Zagorchev L, Odjakova M, Stoyneva M. Microscopic investigations (LM, TEM and SEM) and identification of Chlorella isolate R-06/2 from extreme habitat in Bulgaria with a strong biological activity and resistance to environmental stress factors. Biotechnol Biotechnol Equip. 2015;29:536-40.

34. Polonini HC, Brandao HM, Raposo NRB, Brandao MAF, Mouton L, Coute A, Yepremian C, Sivry Y, Brayner R. Size-dependent ecotoxicity of barium titanate particles: the case of Chlorella vulgaris green algae. Ecotoxicology. 2015:24:938-48

35. Moreno B, Urbina JA, Oldfield E, Bailey BN, Rodrigues CO, Docampo R. ${ }^{31}$ P NMR spectroscopy of Trypanosoma brucei, Trypanosoma cruzi, and Leishmania major. Evidence for high levels of condensed inorganic phosphates. J Biol Chem. 2000;275:28356-62.

36. Read EK, Ivancic M, Hanson P, Cade-Menun BJ, McMahon KD. Phosphorus speciation in a eutrophic lake by ${ }^{31} \mathrm{P}$ NMR spectroscopy. Water Res. 2014;62:229-40.

37. Harold FM. Inorganic polyphosphates in biology: structure, metabolism, and function. Bacteriol Rev. 1966;30:772-94.

38. Zhao J, Xue Y, Qiu R, Guo W, Fan L, Wang P. Superoleophilic Ulva prolifera for oil/water separation: a repayment from the green tide. Chem Eng J. 2016;292:147-55.

39. Li X, Hu HY, Gan K, Sun YX. Effects of different nitrogen and phosphorus concentrations on the growth, nutrient uptake, and lipid accumulation of a freshwater microalga Scenedesmus sp. Bioresour Technol. 2010;101:5494-500.

40. Zhu S, Wang Y, Xu J, Shang C, Wang Z, Xu J, Yuan Z. Luxury uptake of phosphorus changes the accumulation of starch and lipid in Chlorella sp. under nitrogen depletion. Bioresour Technol. 2015;198:165-71.

41. Shen XF, Liu JJ, Chauhan AS, Hu H, Ma LL, Lam PKS, Zeng RJ. Combining nitrogen starvation with sufficient phosphorus supply for enhanced biodiesel productivity of Chlorella vulgaris fed on acetate. Algal Res. 2016;17:261-7.

42. Wu YH, Yu Y, Hu HY. Microalgal growth with intracellular phosphorus for achieving high biomass growth rate and high lipid/triacylglycerol content simultaneously. Bioresour Technol. 2015;192:374-81.

43. Meza B, de-Bashan LE, Hernandez JP, Bashan Y. Accumulation of intra-cellular polyphosphate in Chlorella vulgaris cells is related to indole-3-acetic acid produced by Azospirillum brasilense. Res Microbiol. 2015;166:399-407.
44. Yakovlev A, Tsodikov AD, Bass L. A stochastic model of hormesis. Math Biosci. 1993;116:197-219.

45. Liu Y, Chen S, Chen X, Zhang J, Gao B. Interactions between Microcystis aeruginosa and coexisting amoxicillin contaminant at different phosphorus levels. J Hazard Mater. 2015;297:83-91.

46. BrembuT, Muhlroth A, Alipanah L, Bones AM. The effects of phosphorus limitation on carbon metabolism in diatoms. Philos Trans R Soc Lond B. 2017;372:20160406.

47. Rozas EE, Freitas JC. Intracellular increase of glutamate in neuoblatoma cells induced by polar substances of Galaxaura marginata (Rhodophyta, Nemaliales). Rev Bras Farmacogn. 2008;18:53-62.

48. Cadenas E, Davies KJ. Mitochondrial free radical generation, oxidative stress, and aging. Free Radic Biol Med. 2000;29:222-30.

49. Hu X, Lu K, Mu L, Kang J, Zhou Q. Interactions between graphene oxide and plant cells: regulation of cell morphology, uptake, organelle damage, oxidative effects and metabolic disorders. Carbon. 2014;80:665-76.

50. Gayen RN, Hussain S, Bhar R, Pal AK. Synthesis and characterization of indium phosphide films prepared by co-evaporation technique. Vacuum. 2012;86:1240-7.

51. Kitazaki C, Numano S, Takanezawa A, Nishizawa T, Shirai M, Asayama M. Characterization of lysis of the multicellular cyanobacterium Limnothrix/Pseudanabaena sp. strain ABRG5-3. Biosci Biotechnol Biochem. 2013;77:2339-47.

52. McLennan AG. Dinucleoside polyphosphates-friend or foe? Pharmacol Ther. 2000;87:73-89.

53. Boonaert CJ, Rouxhet PG. Surface of lactic acid bacteria: relationships between chemical composition and physicochemical properties. Appl Environ Microbiol. 2000;66:2548-54.

54. Rodriques PC, Muraro M, Garcia CM, Souza GP, Abbate M, Schreiner WH, Gomes MAB. Polyaniline/lignin blends: thermal analysis and XPS. Eur Polym J. 2001:37:2217-23.

55. Choe HW, Kim YJ, Park JH, Morizumi T, Pai EF, Krauss N, Hofmann KP, Scheerer P, Ernst OP. Crystal structure of metarhodopsin II. Nature. 2011;471:651-5.

56. Law CJ, Maloney PC, Wang DN. Ins and outs of major facilitator superfamily, antiporters. Annu Rev Microbiol. 2008;62:289-305.

57. Qiu Z, Dubin AE, Mathur J, Tu B, Reddy K, Miraglia LJ, Reinhardt J, Orth AP, Patapoutian A. SWELL1, a plasma membrane protein, is an essential component of volume-regulated anion channel. Cell. 2014;157:447-58.

\section{Publisher's Note}

Springer Nature remains neutral with regard to jurisdictional claims in published maps and institutional affiliations.

Ready to submit your research? Choose BMC and benefit from

- fast, convenient online submission

- thorough peer review by experienced researchers in your field

- rapid publication on acceptance

- support for research data, including large and complex data types

- gold Open Access which fosters wider collaboration and increased citations

- maximum visibility for your research: over $100 \mathrm{M}$ website views per year

At BMC, research is always in progress.

Learn more biomedcentral.com/submissions 